\title{
Salinity induced changes in water relations, oxidative damage and morpho- physiological adaptations of pistachio genotypes in soilless culture
}

\author{
Zahra MIRFATTAHI ${ }^{1}$, Soheil KARIMI ${ }^{1 *}$, Mahmoud Reza ROOZBAN ${ }^{1}$
}

Received November 19, 2016; accepted August 03, 2017.

Delo je prispelo 19. novembra 2016, sprejeto 03. avgusta 2017.

\begin{abstract}
Selecting salt tolerant rootstocks is a sustainable approach for developing fruit trees in salinity prone areas. 60-day-old seedlings of Pistacia vera 'Akbari' and 'Ghazvini', and $P$. vera 'Ghazvini' $\times P$. atlantica $(\mathrm{G} \times \mathrm{A})$ were subjected to 0,50 , 100 and $150 \mathrm{mM} \mathrm{NaCl}$ in half strength Hoagland's nutrient solution. After 45 days, the growth, water relations, and oxidative damage parameters were investigated. Salt stress reduced plant biomass, height, crown diameter and leaf number, but increased specific leaf area (SLA) of the seedlings. Under salt stress, the growth of 'Akbari' seedlings was higher than the other genotypes. Accumulation of malondialdehyde (MDA) and proline was observed in the leaves of salt affected seedlings. 'Ghazvini' seedlings had the highest MDA concentration and the lowest cell membrane stability in their leaves. Degredation of photosynthetic pigments under salt stress was lower in the leaves of 'Akbari' seedlings than that in other genotypes. Increase in leaf succulence was observed in 'Akbari' and $\mathrm{G} \times \mathrm{A}$ seedlings in response to salt stress. Relative water content and concentration of anthocyanins in the leaves of pistachio genotypes remained unchanged under salt stress. The results revealed that monitoring leaf abscission, SLA, leaf succulence, MDA concentration, and photosynthetic pigments provide suitable contrast for screening salt tolerance in pistachio. Furthuremore, 'Akbari' was found to be the most salt tolerant genotype.
\end{abstract}

Key words: interspecific hybrid; leaf pigments; morphophysiological adaptation; salt stress; oxidative stress; Pistacia vera

\section{IZVLEČEK}

\section{S SLANOSTJO VZPODBUJENE SPREMEMBE $\mathrm{V}$ VODNEM REŽIMU, OKSIDATIVNE POŠKODBE IN MORFOLOŠKO-FIZIOLOŠKE PRILAGODITVE GENOTIPOV PISTACIJE V BREZTALNEM GOJENJU}

Izbor na slanost tolerantnih podlag je primeren pristop pri razvoju sadnih dreves na območjih podvrženih zasoljevanju. 60-dni stare sejanke pistacije (Pistacia vera 'Akbari' in 'Ghazvini', ter $P$. vera 'Ghazvini' $\times P$. atlantica $(\mathrm{G} \times \mathrm{A}))$ so bile izpostavljene $0,50,100$ in $150 \mathrm{mM} \mathrm{NaCl} \mathrm{v} \mathrm{polovični}$ Hoaglandovi hranilni raztopini. Parametri rasti, vodnih razmer in oksidativnih poškodb so bili preučeni po 45 dneh. Solni stres je zmanjšal biomaso rastlin, višino, premer krošnje in število listov, a povečal specifično listno površino (SLA) sejank. Pod solnim stresom je bila rast sejank 'Akbari' večja kot drugih genotipov. Akumulacija malondialdehida (MDA) in prolina je bila opažena $\mathrm{v}$ listih od soli prizadetih sejank. Sejanke 'Ghazvini' so imele največjo koncentracijo MDA in najmanjšo stabilnost celičnih membran listov. Razgradnja fotosinteznih pigmentov $\mathrm{v}$ listih sejank 'Akbari'je bila v solnem stresu manjša kot pri drugih genotipih. Povečanje sukulence listov kot odziv na solni stres je bilo opaženo pri sejankah 'Akbari' and $\mathrm{G} \times \mathrm{A}$. Relativna vsebnost vode in vsebnost antocianinov $\mathrm{v}$ listih sta pri vseh genotipov pistacije ostali nespremenjeni v solnem stresu. Izsledki so odkrili, da daje spremljanje odpadanja listov, SLA, listne sukulence, koncentracije MDA in fotosinteznih pigmentov primernen nabor znakov za odkrivanje tolerance na sol pri pistaciji. 'Akbari' je bil prepoznan kot na sol najbolj tolranten genotip.

Ključne besede: medvrstni križanci; listni pigmenti; morfološko-fiziološke adaptacije; solni stres; oksidativni stres; Pistacia vera

\section{INTRODUCTION}

Salinity is one of the most serious constraints to agricultural crop production in arid and semi-arid areas. More than 1.5 Mha of irrigated lands are taken out of production each year due to high salt accumulation in the soil (Munns and Tester, 2008). Salinity reduces the growth and development of plant by affecting water availability to plant, absorption of mineral nutrients, and ion homeostasis (Parida and Dos, 2005). Furthermore,

\footnotetext{
1 Department of Horticultural Science, College of Aburaihan, University of Tehran, Tehran, Iran; *Corresponding author: skarimi@ ut.ac.ir
} 
burst of regeneration of reactive oxygen species (ROS) under this situation damages proteins, lipids and the genetic material (Gill and Tuteja, 2010). Morphological, physiological, and biochemical adaptations to salt stress, such as stomatal closure, osmotic adjustment, ion exclusion and compartmentation, and increase in the antioxidative activity have been widely discussed in the literature (Hishida et al., 2014).

Pistachio (Pistacia vera L.) is originally native to arid and semi-arid regions of the middle east and Persia. Although the plant is relatively salt tolerant (Ferguson et al., 2002), intensified salt built up in the soil of these regions due to using poor quality water for irrigation in association with frequent drought periods has reduced its production over recent decades (Karimi and Rahemi, 2012). Selecting salt tolerant rootstocks is an effective approach for sustainable development of pistachio in such salt prone areas. In this regard, understanding the effects of salinity on pistachio is of a crucial importance for establishing a successful rootstock breeding program.
Although there are many reports on evaluating salt tolerance of pistachio genotypes and related species, some controversies in results of these researches can be found. The issue is mainly due to physico-chemical differences in growing media, and using convenient criteria for evaluating salt tolerance of pistachio which are mainly developed for herbaceous annual crop species. However, performing such experiments in soilless culture may reduce experimental errors by increasing uniformity of growing medium. Absence of complex interactions between soil, the stressor, and plant in soilless condition enhances repeatability of results and provide a clear understanding of the plant responses to salinity. Therefore, in this study the effects of salt stress were evaluated on the growth, morphophysiological adaptations, and biochemical characteristics of pistachio seedlings in soilless culture in order to screen salt tolerance. Moreover, effectiveness of different criteria for screening salt tolerance in pistachio seedlings was investigated.

\section{MATERIAL AND METHODS}

\subsection{Plant material and experimental conditions}

This study was conducted at the Department of Horticultural Science of University of Tehran in 201415. Seeds of pistachio 'Ghazvini' and 'Akbari' were obtained from Pistachio Research Station of Damghan, Iran. Seeds of interspecific hybrid $P$. vera 'Ghazvini' $\times$ $P$. atlantica Desf. $(\mathrm{G} \times \mathrm{A})$ were obtained by controlled hybridization (Morovati, 2013). The seeds were soaked for $24 \mathrm{hrs}$ and then treated with $0.2 \%$ captain fungicide for $4 \mathrm{hrs}$. The seeds were transferred to clean containers with moistened filter paper and allowed to germinate for 5 days at room temperature. Three germinated seeds were sown in 4.5 liter plastic pots containing $3.0 \mathrm{~kg}$ of coco-peat and perlite mixture (2:1 volume ratio) in a greenhouse with average day/night temperatures of $30 / 24{ }^{\circ} \mathrm{C}$ and air humidity of $10 / 22 \%$. The pots were irrigated with tap water for about 30 days. At four leaved stage, the seedlings started to receive halfstrength Hoagland's nutrient solution (Hogland and Arnon, 1950) for a 60-day period and then subjected to four $\mathrm{NaCl}$ concentrations $(0,50,100$ and $150 \mathrm{mM})$ in the nutrient solution for 45 days. The seedlings were irrigated with the nutrient solutions every $48 \mathrm{hrs}$. To avoid salt build-up in the pots, the plants were irrigated enough to ensure drainage of $30 \%$ of the solutions.

\subsection{Growth parameters}

After 45 days of exposure to the salt stress plant height, leaf number and crown diameter of the seedlings were measured. Then, the plants were harvested and their fresh mass and dry mass were determined. Specific leaf area (SLA) was measured by determining dry mass of fifteen leaf discs $(0.90 \mathrm{~cm}$ diameter $)$ from the $4-5^{\text {th }}$ fully expanded leaves from shoot top according to Eq. 1:

SLA $=$ Leaf area/Leaf dry mass $\quad$ Eq. 1

\subsection{Water relations}

Leaf water potential $\left(\Psi_{\text {Leaf }}\right)$ was measured at midday (11:00-12:00) using a portable pressure chamber device (Soil Moisture Equipment Corp., USA). $\Psi_{\text {Leaf }}$ was measured immediately after excising the $4-5^{\text {th }}$ fully expanded leaves from the top of the stem. Leaf relative water content (RWC) was measured by punching fifteen discs $(0.90 \mathrm{~cm}$ diameter $)$ from the developed leaves. The discs were weighted (FM), floated on distillated water for $24 \mathrm{hrs}$ (at $4 \mathrm{C}$ in dark) to obtain turgid mass (TM), and finally their dry mass was recorded $72 \mathrm{hrs}$ after placing at $70^{\circ} \mathrm{C}(\mathrm{DM})$. RWC was calculated according to Eq. 2:

$\mathrm{RWC}=\frac{\mathrm{FM}-\mathrm{DM}}{\mathrm{TM}-\mathrm{DM}} \times 100$

Eq. 2

Leaf water content was expressed as the percentage equivalent of the ratio of the mass of water (FM - DM) to the leaf dry matter $\left(\mathrm{M}_{\mathrm{d}}\right)$ (Eq. 3).

Leaf water content $=\frac{\text { FM-DM }}{\text { Md }} \times 100 \quad$ Eq. 3

Area basis leaf water content (succulence index) was expressed as the ratio of the mass of water to the area of 
the leaf sample $\left(\mathrm{LA}_{\mathrm{S}}\right)$. In this order, fifteen foliar discs $(0.90 \mathrm{~cm}$ diameter $)$ from the developed leaves of shoot top were used (Eq. 4).

$$
\text { Succulence }=\frac{\text { FM-DM }}{\text { LAS }}
$$$$
\text { Eq. } 4
$$

\subsection{Leaf proline concentration}

Leaf proline concentration was measured according to the method described by Bates et al. (1973). Leaf tissue $(0.1 \mathrm{~g})$ was extracted in $10 \mathrm{ml}$ of $3 \%$ sulphosalicylic acid and then, $2 \mathrm{ml}$ of ninehydrin reagent and $2 \mathrm{ml}$ acetic acid were added to $2 \mathrm{ml}$ of the extract. Then, the samples were heated in boiling water for $60 \mathrm{~min}$. Four milliliters of toluene was added to each sample and vortexed for 15-20 seconds. The absorbance of toluene phase was measured at $532 \mathrm{~nm}$ using a spectrophotometer (Perkin Elmer, Lambada 25, USA). The concentration of proline was determined according to an external standard curve.

\subsection{Oxidative damage parameters}

Cell membrane stability index (CMS) was determined by measurement of electrolyte leakage from leaf samples. Fifteen leaf discs $(0.90 \mathrm{~cm}$ diameter $)$ were excised from fully expanded young leaves. The leaf discs were washed three times in deionized water and incubated in $15 \mathrm{ml}$ deionized water $\left(40^{\circ} \mathrm{C}\right)$ for $30 \mathrm{~min}$. The initial conductance $(\mathrm{C} i)$ of the incubation solution was measured using an electrical conductance meter. Leaf tissue in the incubation solution was killed by placing the samples in boiling water for $10 \mathrm{~min}$. The conductance of the solution (Cmax) was determined at room temperature. CMS was calculated by using the following formula (Eq. 5):

$\mathrm{CMS}=1-\left(\mathrm{Ci} / \mathrm{Cmax}_{\max }\right) \times 100$

Lipid peroxidation was assessed by measurement of malondialdehyde (MDA) concentration in fully expanded young leaves, according to the method described by Heath and Parker, (1986). Leaf tissue $(200 \mathrm{mg})$ was homogenized in $10 \mathrm{ml}$ of $0.1 \%$ trichloroacetic acid (TCA) and centrifuged at $1000 \mathrm{~g}$ for
5 min. Then $4 \mathrm{ml}$ TCA acid $20 \%$ and thiobarbituric acid $0.15 \%$ were added to $1 \mathrm{ml}$ of the supernatant. The absorbance was measured at $532 \mathrm{~nm}$ by spectrophotometry (PerkinElmer, Lambda 25, USA).

\subsection{Leaf pigments}

In addition to evaluation of leaf greenness by using a SPAD 502 chlorophyll meter (Minolta Co., Japan), concentrations of chlorophylls and carotenoids were measured in the $4-5^{\text {th }}$ developed leaves according to the method described by Lichtenthaler (1987). Fresh tissue $\left(15 \times 0.64 \mathrm{~cm}^{2}\right.$ leaf discs) was extracted in $80 \%$ acetone and after centrifuging at $4800 \mathrm{rpm}$ for $20 \mathrm{~min}$, the absorption of supernatant was read at 470, 647 and $664 \mathrm{~nm}$ using a spectrophotometer (PerkinElmer, Lambda 25, USA). The concentrations of chlorophyll a (Chl a) and b (Chl b), and carotenoids were calculated according to the following formulas (Eq. 6-8):

$\mathrm{Chl} \mathrm{a}=12.25 \mathrm{~A}_{664}-2.79 \mathrm{~A}_{647} \quad$ Eq. 6

$\mathrm{Chl} \mathrm{b}=21.51 \mathrm{~A}_{647}-5.10 \mathrm{~A}_{664} \quad$ Eq. 7

Carotenoids $=\left(1000 \mathrm{~A}_{470}-1.8 \mathrm{C}_{a}-85.02 \mathrm{C}_{b}\right) / 198 \quad$ Eq. 8

For measuring anthocyanins, $500 \mathrm{mg}$ fresh leaf tissue was extracted in $10 \mathrm{ml}$ of methanol acidified with $1 \%$ $\mathrm{HCl}$ at $4{ }^{\circ} \mathrm{C}$ for $24 \mathrm{hrs}$. The absorbance of the extract was determined at $550 \mathrm{~nm}$ using a spectrophotometer (PerkinElmer, Lambda 25, USA). Anthocyanin concentration was calculated using an extinction coefficient of $33000 \mathrm{~mol}^{-1} \mathrm{~cm}^{-1}$ (Wagner, 1979).

\subsection{Statistical analyses}

The experiment was conducted as factorial (3 genotypes $\times 4 \mathrm{NaCl}$ concentrations) based on a completely randomized design with three replications. Three pots were considered in each replication and mean of these pots were considered as a replication for each treatment. In sum, 108 pots were used in the experiment. The data were subjected to ANOVA and the means were compared using Duncan's multiple range test (DMRT) at $P \leq 0.05$. The statistical analyses were performed using the SPSS software (v. 21.0).

\section{RESULTS}

The effects of salt stress on growth of pistachio seedlings are represented in Table 1. Shoot height, crown diameter, leaf number, and dry mass of the seedlings were significantly reduced under 100 and $150 \mathrm{mM} \mathrm{NaCl}$ treatments. Shoot height and leaf number of 'Akbari' seedlings were significantly higher than the other genotypes. Trunk diameter of 'Akbari' seedlings was significantly higher than the other genotypes and the lowest value was found in $\mathrm{G} \times \mathrm{A}$. Fresh mass of the seedlings significantly decreased by increasing $\mathrm{NaCl}$ concentration in the nutrient solution. Among the genotypes, seedlings of 'Akbari' had the highest fresh and dry mass at the end of the experiment; no significant differences were observed between fresh and dry mass of 'Ghazvini' and $\mathrm{G} \times \mathrm{A}$ seedlings. SLA significantly increased under 100 and $150 \mathrm{mM} \mathrm{NaCl}$ treatments. The highest SLA was found in $\mathrm{G} \times \mathrm{A}$ and 'Akbari' seedlings had the lowest SLA. 
Zahra MIRFATTAHI et al.

Table 1: The effects of salt stress and plant genotype on growth of pistachio seedlings

\begin{tabular}{lllllll}
\hline & $\begin{array}{l}\text { Plant height } \\
(\mathrm{cm})\end{array}$ & $\begin{array}{l}\text { Crown diameter } \\
(\mathrm{mm})\end{array}$ & Leaf number & $\begin{array}{l}\text { Fresh mass } \\
(\mathrm{g})\end{array}$ & $\begin{array}{l}\text { Dry mass } \\
(\mathrm{g})\end{array}$ & $\begin{array}{l}\text { SLA } \\
\left(\mathrm{cm}^{2} \mathrm{~g}^{-1}\right)\end{array}$ \\
\hline $\begin{array}{l}\text { Genotype } \\
\text { Akbari }\end{array}$ & $40.3^{\mathrm{a} \dagger}$ & $5.79^{\mathrm{a}}$ & $22.9^{\mathrm{a}}$ & $81.0^{\mathrm{a}}$ & $36.1^{\mathrm{a}}$ & $0.010^{\mathrm{b}}$ \\
Ghazvini & $35.1^{\mathrm{b}}$ & $4.78^{\mathrm{b}}$ & $19.2^{\mathrm{b}}$ & $56.6^{\mathrm{b}}$ & $24.7^{\mathrm{b}}$ & $0.011^{\mathrm{ab}}$ \\
$\mathrm{G} \times \mathrm{A}$ & $32.9^{\mathrm{b}}$ & $4.44^{\mathrm{c}}$ & $18.5^{\mathrm{b}}$ & $47.8^{\mathrm{b}}$ & $20.7^{\mathrm{b}}$ & $0.012^{\mathrm{a}}$ \\
$N a C l(m M)$ & & & & & \\
0 & $39.9^{\mathrm{a}}$ & $5.43^{\mathrm{a}}$ & $24.6^{\mathrm{a}}$ & $77.2^{\mathrm{a}}$ & $35.0^{\mathrm{a}}$ & $0.010^{\mathrm{b}}$ \\
50 & $35.8^{\mathrm{ab}}$ & $5.12^{\mathrm{ab}}$ & $21.7^{\mathrm{ab}}$ & $65.5^{\mathrm{b}}$ & $28.4^{\mathrm{bb}}$ & $0.010^{\mathrm{b}}$ \\
100 & $33.8^{\mathrm{b}}$ & $4.87^{\mathrm{bc}}$ & $18.8^{\mathrm{bc}}$ & $53.1^{\mathrm{c}}$ & $23.6^{\mathrm{b}}$ & $0.012^{\mathrm{a}}$ \\
150 & $34.2^{\mathrm{b}}$ & $4.63^{\mathrm{c}}$ & $16.2^{\mathrm{c}}$ & $48.5^{\mathrm{c}}$ & $21.5^{\mathrm{c}}$ & $0.012^{\mathrm{a}}$ \\
\hline ANOVA & & & & & $*$ \\
\hline Genotype & $* *$ & $* *$ & $*$ & $* *$ & $* *$ \\
NaCl Level & $*$ & $* *$ & $* *$ & $* *$ & & $* *$ \\
NaCl $\times$ Genotype & $\mathrm{ns}$ & $\mathrm{ns}$ & $\mathrm{ns}$ & $\mathrm{ns}$ & $\mathrm{ns}$ & $\mathrm{ns}$ \\
\hline
\end{tabular}

Difference among the treatments was analyzed by 3 genotypes $\times 4$ salt stress ANOVA; ns, *, ** indicate nonsignificant, and significant differences at 0.05 and 0.01 , respectively. The data are means of 3 replicates; Mean separation was performed according to DMRT $(P \leq 0.05)$ and similar letters indicate no significant difference between mean values.

Relative water content (RWC) and water potential $\left(\Psi_{\text {Leaf }}\right)$ of the leaves were not affected by the $\mathrm{NaCl}$ treatments. However, $\Psi_{\text {Leaf }}$ was significantly higher in the leaves of 'Akbari' seedlings $(-0.68 \mathrm{MPa})$ and the lowest value $(-0.892 \mathrm{MPa})$ was found in 'Ghazvini' leaves (Table 2). Leaf water content and succulence were significantly affected by the interactive effects of salt stress and plant genotype $(P \leq 0.01)$. Water content significantly increased in the leaves of 'Akbari' and $\mathrm{G} \times \mathrm{A}$ under 100 and $150 \mathrm{mM} \mathrm{NaCl}$ stress up to 21 and 41 percent, respectively. However, no significant changes were observed in leaf water content of 'Ghazvini' under salt stress (Figure 1). Unlike the other genotypes, area basis leaf water content was significantly reduced in the leaves of 'Ghazvini' under $150 \mathrm{mM} \mathrm{NaCl}$ by 16.2 percent (Figure 1).
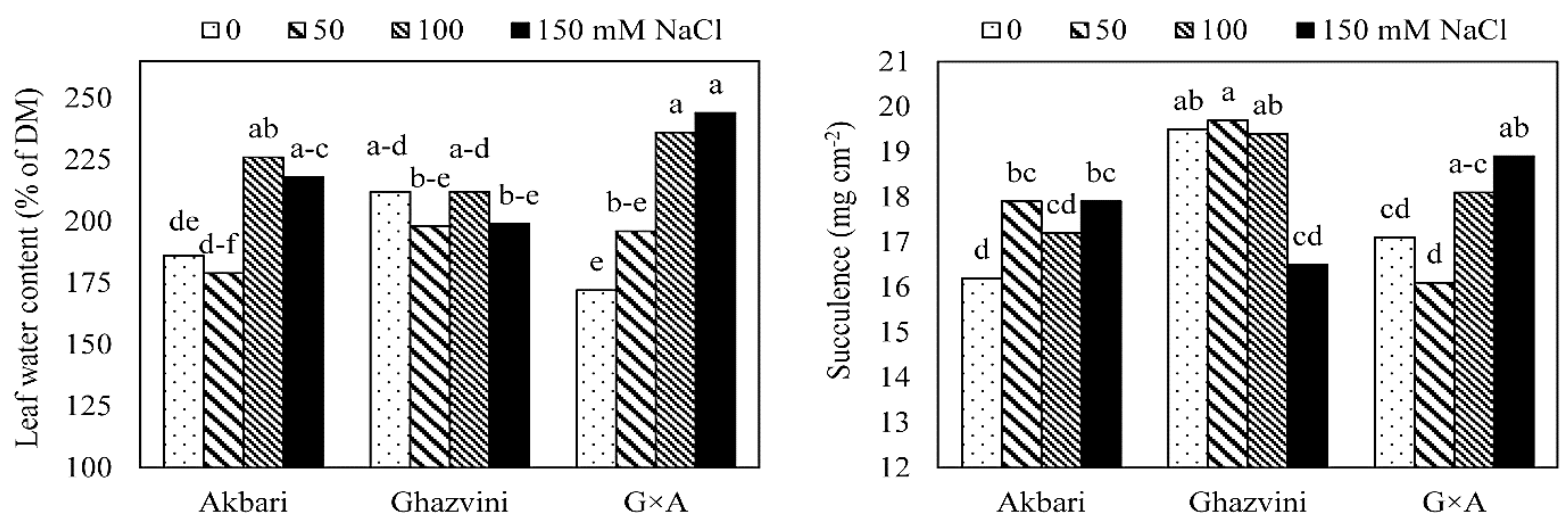

Figure 1: The interactive effects of salt stress and genotype on water content and succulence of the leaves of pistachio seedlings. Mean separation according to DMRT at $P \leq 0.05(\mathrm{n}=3)$

Significant increase in leaf proline concentration was observed under severe salt stress. Among the genotypes, 'Ghazvini' and 'Akbari' had more leaf proline content than $\mathrm{G} \times \mathrm{A}$ (Table 2). Cell membrane stability index (CMS) remained unchanged under salt stress, too (Table 2). However, CMS in the leaves of 'Ghazvini' was significantly lower than the other genotypes. Significant accumulation of malondialdehyde (MDA) concentration was found in the leaves of the seedlings under salt stress and the highest increase in MDA concentration (45.9\%) was observed under $150 \mathrm{mM} \mathrm{NaCl}$ treatment. $\mathrm{G} \times \mathrm{A}$ had the highest leaf MDA concentration $\left(15.5 \mathrm{mmol} \mathrm{g}^{-1}\right)$, and the lowest concentration $\left(10.56 \mathrm{mmol} \mathrm{g}^{-1}\right)$ was found in 'Akbari' (Table 2). 
Table 2: The effects of salt stress and plant genotype on relative water content (RWC), water potential $\left(\Psi_{\text {Leaf }}\right)$, proline, cell membrane stability index (CMS), and concentration of malondialdehyde (MDA) in the leaves of pistachio seedlings

\begin{tabular}{llllll}
\hline & $\begin{array}{l}\text { RWC } \\
(\%)\end{array}$ & $\begin{array}{l}\Psi_{\text {Leaf }} \\
(\mathrm{MPa})\end{array}$ & $\begin{array}{l}\text { Proline } \\
\left.(\mu \mathrm{mol} \mathrm{g})^{-1}\right)\end{array}$ & $\begin{array}{l}\text { CMS } \\
(\%)\end{array}$ & $\begin{array}{l}\text { MDA } \\
\left(\mathrm{mmol} \mathrm{g}^{-1}\right)\end{array}$ \\
\hline $\begin{array}{l}\text { Genotype } \\
\text { Akbari }\end{array}$ & 83.3 & $-0.680^{\mathrm{a} \uparrow}$ & $267.8^{\mathrm{ab}}$ & $90.7^{\mathrm{a}}$ & $10.65^{\mathrm{b}}$ \\
Ghazvini & 84.0 & $-0.892^{\mathrm{b}}$ & $296.7^{\mathrm{a}}$ & $83.5^{\mathrm{b}}$ & $12.26^{\mathrm{ab}}$ \\
$\mathrm{G} \times \mathrm{A}$ & 85.3 & $-0.744^{\mathrm{ab}}$ & $218.1^{\mathrm{b}}$ & $92.1^{\mathrm{a}}$ & $15.50^{\mathrm{a}}$ \\
$N a C l(m M)$ & & & & & \\
0 & 84.2 & -0.851 & $231.2^{\mathrm{b}}$ & 88.8 & $10.72^{\mathrm{b}}$ \\
50 & 84.0 & -0.683 & $258.2^{\mathrm{b}}$ & 90.7 & $11.94^{\mathrm{ab}}$ \\
100 & 85.3 & -0.755 & $271.0^{\mathrm{ab}}$ & 88.2 & $13.25^{\mathrm{ab}}$ \\
150 & 83.6 & -0.851 & $283.3^{\mathrm{a}}$ & 87.0 & $15.65^{\mathrm{a}}$ \\
\hline ANOVA & & & & & \\
\hline Genotype & $\mathrm{ns}$ & $* *$ & $*$ & $* *$ & $*$ \\
NaCl Level & $\mathrm{ns}$ & $\mathrm{ns}$ & $*$ & $\mathrm{~ns}$ & $*$ \\
NaCl $\times$ Genotype & $\mathrm{ns}$ & $\mathrm{ns}$ & $\mathrm{ns}$ & $\mathrm{ns}$ & $\mathrm{ns}$ \\
\hline
\end{tabular}

Difference among the treatments was analyzed by 3 genotypes $\times 4$ salt stress ANOVA; ns, *, ** indicate nonsignificant, and significant differences at 0.05 and 0.01 , respectively. The data are means of 3 replicates; Mean separation was performed according to DMRT $(P \leq 0.05)$ and similar letters indicate no significant difference between mean values.

Table 3 represents the effects of salt stress and plant genotype on concentration of leaf pigments. Chlorophyll a:b ratio (Chl a:b) significantly increased in the leaves of pistachio seedlings in response to salt stress. Chl a:b in the leaves of 'Akbari' was significantly lower than the other genotypes. Leaf greenness, which was measured by SPAD, significantly reduced under salt stress. However, no significant difference was observed in leaf color of the genotypes. Salt stress significantly reduced total chlorophyll concentration in the leaves. 'Akbari' had the highest leaf chlorophyll concentration than the other genotypes. Concentration of anthocyanins and carotenoids in the leaves remained unchanged under salt stress, however, concentration of carotenoids in the leaves of 'Akbari' was higher than 'Ghazvini' and $\mathrm{G} \times \mathrm{A}$.

Table 3: The effects of salt stress and plant genotype on concentration of pigments in the leaves of pistachio seedlings

\begin{tabular}{llllll}
\hline & SPAD & Chl a:b & $\begin{array}{l}\text { Total Chls } \\
\left(\mathrm{mg} \mathrm{cm}^{-2}\right)\end{array}$ & $\begin{array}{l}\text { Carotenoids } \\
\left(\mathrm{mg} \mathrm{cm}^{-2}\right)\end{array}$ & $\begin{array}{l}\text { Anthocyanins } \\
\left(\mathrm{mmol} \mathrm{g}^{-1}\right)\end{array}$ \\
\hline $\begin{array}{l}\text { Genotype } \\
\text { Akbari }\end{array}$ & 55.0 & $0.395^{\mathrm{b} \dagger}$ & $29.2^{\mathrm{a}}$ & $2.23^{\mathrm{a}}$ & 280.9 \\
Ghazvini & 55.9 & $0.420^{\mathrm{a}}$ & $25.4^{\mathrm{b}}$ & $2.03^{\mathrm{b}}$ & 282.1 \\
$\mathrm{G} \times \mathrm{A}$ & 56.1 & $0.423^{\mathrm{a}}$ & $23.6^{\mathrm{b}}$ & $1.90^{\mathrm{b}}$ & 282.3 \\
$N a C l(m M)$ & & & & & \\
0 & $57.8^{\mathrm{a}}$ & $0.396^{\mathrm{b}}$ & $27.9^{\mathrm{a}}$ & 2.13 & 289.5 \\
50 & $55.4^{\mathrm{b}}$ & $0.422^{\mathrm{a}}$ & $23.8^{\mathrm{b}}$ & 1.90 & 279.3 \\
100 & $54.6^{\mathrm{b}}$ & $0.421^{\mathrm{a}}$ & $26.8^{\mathrm{ab}}$ & 2.08 & 283.3 \\
150 & $54.9^{\mathrm{b}}$ & $0.416^{\mathrm{a}}$ & $25.2^{\mathrm{b}}$ & 2.06 & 275.3 \\
\hline ANOVA & & & & & \\
\hline Genotype & $\mathrm{ns}$ & $* *$ & $* *$ & $* *$ & $\mathrm{~ns}$ \\
NaCl Level & $*$ & $* *$ & $*$ & $\mathrm{~ns}$ & $\mathrm{~ns}$ \\
NaCl $\times$ Genotype & $\mathrm{ns}$ & $\mathrm{ns}$ & $\mathrm{ns}$ & $\mathrm{ns}$ & $\mathrm{ns}$ \\
\hline Differen & & & & & \\
\hline
\end{tabular}

Difference among the treatments was analyzed by 3 genotypes $\times 4$ salt stress ANOVA; ns, *, ** indicate nonsignificant, and significant differences at 0.05 and 0.01 , respectively. The data are means of 3 replicates; mean separation was performed according to DMRT $(P \leq 0.05)$ and similar letters indicate no significant difference between mean values. 
Chlorophylls:carotenoids ratio (Chl:Crt) was significantly affected by the interactive effect of salt stress and plant genotype $(P \leq 0.01)$. Chl:Crt ratio remained unchanged in the leaves of salt stressed
'Akbari' and 'Ghazvini' seedlings. A significant decrease in Chl:Crt ratio was found in the leaves of $\mathrm{G} \times \mathrm{A}$ under salt stress (Figure 2).



Figure 2: The interactive effects of salt stress and plant genotype on chlorophylls:carotenoids ratio (Chl:Crt) in the leaves of pistachio seedlings. Mean separation according to DMRT at $P \leq 0.05(\mathrm{n}=3)$

\section{DISCUSSION}

\subsection{Plant growth}

The growth and biomass of pistachio genotypes reduced with increasing $\mathrm{NaCl}$ concentration in the nutrient solution. This was in accordance with the earlier reports on studying pistachio responses to salt stress (Hokmabadi et al., 2005; Tavallali et al., 2008; Karimi et al., 2009). Limitation of plant growth under salt stress can be attributed to osmotic stress, leaf injuries, and reduced photosynthesis active area (Wahome et al., 2001). Biomass of $\mathrm{G} \times \mathrm{A}$ and 'Ghazvini' seedlings was significantly lower than that in 'Akbari' seedlings. Munns (2002) stated that salt stress reduces plant growth by causing premature senescence of leaves and reducing supply of assimilates for growth. Leaf abscission is a major cause of loss of biomass and growth inhibition of pistachio under salt stress (Karimi et al., 2009). Necrosis and abscission of leaves of the plants started from the older leaves at the base of stem (Rahemi et al., 2017). Leaf abscission is primarily dependent upon accumulation of $\mathrm{Na}^{+}$and $\mathrm{Cl}^{-}$ions in the leaves (Brumós et al., 2009). Accordingly, rate of leaf abscission under salt stress could indirectly determine plant sensitivity to ionic stress of salinity. In this regard, monitoring leaf abscission indicated that $\mathrm{G} \times \mathrm{A}$ and 'Ghazvini' seedlings were more susceptible to salt stress than 'Akbari' seedlings.

Specific leaf area (SLA) is known to be negatively correlated with relative growth rate (Osone et al., 2008) and water use efficiency of plant (Rao et al., 1995). The higher SLA of $\mathrm{G} \times \mathrm{A}$ and 'Ghazvini' seedlings under salt stress indicated the lower growth rate and higher salt sensitivity of these plants than those in 'Akbari' seedlings (Ball, 2002). Moreover, the increase in SLA of pistachio leaves in response to salt stress indicated that the leaves became thinner due to mesophyll destruction and limitation of photoassimilate accumulation and starch biosynthesis (Sefton et al., 2002). Plants with higher SLA have fewer cells per unit area with lower concentration of chlorophylls in their leaves, which reduce plant photosynthetic capacity and WUE. Such plants have poor performance under salinity (Omamt et al., 2006) and osmotic stress (Karimi et al., 2012). The increase in SLA of pistachio seedlings under salt stress was in accordance with Behboudian et al. (1986) who reported that $\mathrm{NaCl}$ destructs leaf mesophyll and reduces $\mathrm{CO}_{2}$ assimilation and photosynthetic efficiency of pistachio.

Stem diameter changes are usually monitored for investigating tree growth and water transport. Decrease in trunk diameter under salt stress was previously reported in Carya illinoinensis (Wangenh.) K.Koch (Miyamoto et al., 1986), Persea americana Mill. (Bernstein et al., 2001), Pistacia spp. (Ferguson et al. 2002), and Olea europea L. (Aragüés et al., 2005). Yaron et al. (1969) stated that decrease of stem diameter with increasing salt stress was primarily due to leaf abscission. Ashraf and Sarwar (2002) also found that decreased stem diameter under salt stress was due to the reduction in turgor potential and cell division. In sum, the significant decrease in crown diameter of pistachio seedlings confirmed the limitation of photoassimilates 
accumulation in stem and limitation of root function in water transport under salt stress (Escalona et al., 2002). Moreover, the larger crown diameter of 'Akbari' seedlings emphasized on higher growth and performance of this genotype than the others under salt stress.

\subsection{Water relations}

The growth inhibition under salt stress is partially related to water deficiency or osmotic stress, which induces changes in the cell metabolic activity (Jaleel et al., 2007) and reduces cell division and expansion (Taiz and Zeiger, 2006). In the present study, salt stress did not affect RWC of leaves of the pistachio seedlings. Hokmabadi et al. (2005) also reported the same result in pistachio genotypes under salt stress. The significant increase in proline concentration under salt stress revealed that maintenance of RWC in pistachio leaves was owed to accumulation of osmolytes and osmotic adjustment. Accumulation of osmolytes, such as proline, is of curtail importance for water conservation in tissues and preventing cytoplasm dehydration under osmotic stress (Hoekstra et al., 2001). Previous researchers also reported that proline concentration increased in pistachio leaves in response to salt stress (Hokmabadi et al., 2005; Karimi et al., 2009; Karimi et al., 2017). Since the highest leaf proline concentration was extracted from leaves of 'Ghazvini' seedlings with the lowest water content in the leaves, it can be assumed that higher leaf proline concentration reflects osmotic pressure of salt stress on the plants. But, some researchers believe that higher accumulation of proline in the leaves is related to salt tolerance of this species (Hokmabadi et al., 2005; Szabados and Savoure, 2010). This seems not to be a universal fact, since our results indicated that other physiological responses of plant should be considered in drawing conclusions in this respect. 'Akbari' and $\mathrm{G} \times \mathrm{A}$ seedlings were able to preserve leaf RWC with lower proline concentration in their leaves. These observations suggest that mechanisms other than osmoregulation help these plants preserving leaf water content under salt stress.

Stomatal closure is the earliest response of plants for water conserving under water deficit conditions (Flexas and Medrano, 2002; Pérez-López et al., 2009). Studying stomatal characteristics of some pistachio cultivars and species has indicated that 'Ghazvini' has large stomata (Arzani et al., 2013). Therefore, inefficiency of stomatal regulation in its leaves is expected (Bosabalidis and Kofidis, 2002). In this regard, Saadatmand et al. (2007) revealed that the salt tolerance of pistachio 'Ghazvini' is dependent on water availability to this plant. They compared salt tolerance of 'Ghazvini' seedlings with another Persian rootstock, 'Sarakhs', under different irrigation regimes. Their results indicated that 'Ghazvini' was more salt tolerant than 'Sarakhs' at the lowest irrigation intervals; but, with increasing irrigation intervals, 'Ghazvini' turned to the salt sensitive genotype. In contrast with 'Ghazvini', increases in leaf succulence and leaf water content were observed in 'Akbari' and $\mathrm{G} \times \mathrm{A}$ seedlings in responses to salt stress. Increase in leaf succulence is resulted from increase in leaf cell number and volume. This is a common response of many glycophytes to salinity (Kim and Park, 2010) which reduces ion toxicity pressure on plant by diluting the ions in the leaves (Larcher and de Assis Prado, 2000; Ottow et al. 2005). Moreover, succulence is important for regulating leaf temperature and water balance under salinity induced osmotic stress (Fitter and Hay, 2002). Thus, the increased leaf succulenece in 'Akbari' and $\mathrm{G} \times \mathrm{A}$ seedlings considered to be a morphophysiological adaptation to salt stress which reduces the internal salt concentration and ionic pressure (Jennings, 1968). Lack of such adaptation in 'Ghazvini' probably is linked with the higher sensitivity of the plant to salt stress.

\subsection{Oxidative damage}

In addition to ion toxicity, oxidative stress is another cause of leaf injury and necrosis under salt stress (Munns, 2002). Accumulation of toxic ions in cell and experiencing water stress disrupt photosynthesis and photorespiration, alter the homeostasis of cells, and increase the production of reactive oxygen species (ROS). Accumulation of ROS cause oxidative damage to cell membrane and other subcellular structures (Miller et al., 2010). Leaf MDA concentration and CMS are widely determined to evaluate the effects of oxidative damage on plasma membrane integrity under environmental stress (Foyer et al., 1997). MDA is the most abundant individual aldehyde resulting from lipid peroxidation (Dmitriev and Titov, 2010); thus, its accumulation in the leaves of pistachio genotypes under $150 \mathrm{mM} \mathrm{NaCl}$ stress confirmed oxidative damage to the leaf cells. However, salt stress did not affect CMS in the leaves. These observations suggested that accumulation of MDA in the leaves is an earlier response than CMS loss and it can provide a higher contrast in assessment of oxidative damage under salt stress. It should be noted that ion toxicity and leaf necrosis are mainly started from the older leaves on pistachio shoot; therefore, the young and fresh leaves which remain on the plant for evaluating CMS may not reflect the actual pressure of salt stress on the plant. In sum, according to higher leaf MDA content, G $\times A$ and 'Ghazvini' seedlings were found to be more prone to oxidative damage and ion toxicity than 'Akbari' seedlings.

Significant decrease of photosynthetic pigments in the leaves also indicated oxidative damage to cell under salt stress. Since chloroplasts are of the primary sites of ROS production under abiotic stress, the early symptoms of oxidative injuries become evident on 
chloroplast structure and degradation of photosynthetic pigments (Maiale et al., 2004). The significant reductions in total chlorophylls, Chl:Crt ratio and the greenness of the leaves of pistachio genotypes under salt stress were in parallel with MDA accumulation in the leaves. The increase in chlorophyll a:b ratio under salt stress indicated that destruction of chlorophyll b was higher than chlorophyll a (Karimi et al., 2009). This observation indicated structural damages to photosystem II reaction center (Mehta et al., 2010). The lower Chl:Crt ratio in the leaves of 'Ghazvini' and $\mathrm{G} \times \mathrm{A}$ seedlings than that in 'Akbari' seedlings, indicated that the degradation of chlorophylls was higher than carotenoids in the sensitive genotypes. Loss of photosynthetic pigments and structural damage to chloroplasts in salt sensitive pistachio genotypes have been correlated with limitation of photosynthesis rate and the plant growth and productivity under salt stress (Behboudian et al., 1986; Ferguson et al., 2002; Karimi et al., 2009). The higher oxidative stress tolerance of 'Akbari' seedlings than the other genotypes was partially owed to its lower SLA. Low SLA minimizes light capture, while enhances water use efficiency via reducing water loss potential (Field et al., 1983). Higher self-shading within the leaf tissue and higher water conservation capability of the leaves with lower SLA are of crucial importance for reducing the production of ROS under salinity or drought stress situations.

Some leaf pigments and cell antioxidant defense also involve in reducing ROS-derived injury under salt stress (Sevengor et al., 2011). Increase in biosynthesis of sun screen pigments including carotenoids and anthocyanins help plants to cope with excess light energy and reduce ROS production in the leaves (Sherwin and Farrant, 1998). Carotenoids preserve chloroplast structure and prevent degradation of chlorophylls under abiotic stress (Nishida et al., 2007; Karimi et al., 2013; Jain and Gould, 2015). These pigments by regulation of light harvesting by the chlorophyll antenna system of photosystem II, detoxification of ROS and protecting membrane lipids against peroxidation involve in plant defense system against abiotic stresses (Havaux, 2014). Therefore, the higher concentration of carotenoids in the leaves of 'Akbari' may explain lower chlorophyll b destruction in its leaves in comparison with that in other genotypes. Anthocyanin have shown to accumulate in plant vacuoles in response to salinity (Piao et al., 2001; Keutgen and Pawelzik, 2007) and drought stress (Basu et al., 2010; Sperdouli and Moustakas, 2012). Increase in biosynthesis of these pigments is thought to mask chlorophyll and act as filters preventing excess light absorption by the photosynthesis aparathus (Hopkins, 1999). In addition to their photoprotective function (Mittler, 2002), anthocyanins also involve in osmoregulation and ROS scavenging in plant defense network (Jain and Gould, 2015). However, in this study, salt stress did not affect concentration of anthocyanins in the leaves of pistachio seedlings. Chalker-Scott (2002) stated that the toxic effects of $\mathrm{Na}^{+}$and $\mathrm{Cl}^{-}$ions may prevent anthocyanin biosynthesis and accumulation in plant leaves. Furthermore, since biosynthesis of these metabolites is greatly under control of environmental factors, more studies are needed to clarify their role in defense system of this species against salt stress.

\section{CONCLUSION}

In sum, progressive leaf abscission and loss of shoot biomass, limitation of stem growth, and higher SLA of 'Ghazvini' and $\mathrm{G} \times \mathrm{A}$ seedlings under salt stress revealed that these genotypes are more prone to salt stress than 'Akbari' seedlings. The water relations data confirmed that 'Ghazvini' seedlings experienced water stress under severe salt stress. The highest proline accumulation in the leaves of 'Ghazvini' was in parallel with water deficit development in its leaves. Therefore, leaf proline concentration is a good indicator of osmotic stress pressure on pistachio plants. Increase in leaf succulence and leaf water content indicated morpho-physiological adaptations in the leaves of 'Akbari' and $\mathrm{G} \times \mathrm{A}$, which reduced ion toxicity in their leaves. However, higher MDA concentration and chlorophyll degradation in the leaves of $\mathrm{G} \times \mathrm{A}$ seedlings revealed that this genotype is prone to oxidative stress. The higher concentration of carotenoids in the leaves of 'Akbari' protected the photosynthetic apparatus and improve oxidative tolerance of this genotype. Moreover, the higher oxidative stress tolerance of 'Akbari' seedlings was partially related to their lower leaf SLA, which resulted in higher self-shading and lower water loss potential in their leaves.. 


\section{REFERENCES}

Aragüés, R., Puy, J., Royo, A. and Espada, J. L. (2005). Three-year field response of young olive trees (Olea europaea L., cv. Arbequina) to soil salinity: trunk growth and leaf ion accumulation. Plant and Soil, 271(1-2), 265-273. doi:10.1007/s11104-0042695-9

Arzani, K., Ghasemi, M., Yadollahi, A. and Hokmabadi, H. (2013). Study of foliar epidermal anatomy of four pistachio rootstocks under water stress. Idesia (Arica), 31(1), 101-107. doi:10.4067/S071834292013000100012

Ashraf, M. Y. and Sarwar, G. (2002). Salt tolerance potential in some members of Brassicaceae physiological studies on water relations and mineral contents. Prospects for Saline Agriculture, 237245. doi:10.1007/978-94-017-0067-2_26

Ball, M. C. (2002). Interactive effects of salinity and irradiance on growth: implications for mangrove forest structure along salinity gradients. Trees, 16(2), 126-139. doi:10.1007/s00468-002-0169-3

Basu, S., Roychoudhury, A., Saha, P. P. and Sengupta, D. N. (2010). Differential antioxidative responses of indica rice cultivars to drought stress. Plant Growth Regulation, 60(1), 51. doi:10.1007/s10725009-9418-4

Bates, L. S., Waldren, R. P. and Teare, I. D. (1973). Rapid determination of free proline for water stress studies. Plant and Soil, 39(1), 205-207. doi:10.1007/BF00018060

Behboudian M. H., Walker R. R., Torokfaivy, E. (1986). Effects of water stress and salinity on photosynthesis of pistachio. Scientia Horticulturae, 29, 251-261. doi:10.1016/0304-4238(86)90068-3

Bernstein, N., Ioffe, M. and Zilberstaine, M. (2001). Salt-stress effects on avocado rootstock growth. I. Establishing criteria for determination of shoot growth sensitivity to the stress. Plant and Soil, 233(1), 1-11. doi:10.1023/A:1010370802773

Bosabalidis, A. M. and Kofidis, G. (2002). Comparative effects of drought stress on leaf anatomy of two olive cultivars. Plant Science, 163(2), 375-379. doi:10.1016/S0168-9452(02)00135-8

Brumós, J., Colmenero-Flores, J. M., Conesa, A., Izquierdo, P., Sánchez, G., Iglesias, D. J., LópezCliment, M. F., Gómez-Cadenas, A. and Talón, M. (2009). Membrane transporters and carbon metabolism implicated in chloride homeostasis differentiate salt stress responses in tolerant and sensitive Citrus rootstocks. Functional and
Integrative Genomics, 9(3), 293-309. doi:10.1007/s10142-008-0107-6

Chalker-Scott, L. (2002). Do anthocyanins function as osmoregulators in leaf tissues?. Advances in Botanical Research,37, 103-127. doi:10.1016/S0065-2296(02)37046-0

Dmitriev, L. F. and Titov, V. N. (2010). Lipid peroxidation in relation to ageing and the role of endogenous aldehydes in diabetes and other agerelated diseases. Ageing Research Reviews, 9(2), 200-210. doi:10.1016/j.arr.2009.09.004

Escalona, J., Flexas, J. and Medrano, H. (2002). Drought effects on water flow, photosynthesis and growth of potted grapevines. Vitis, 41(2), 57-62.

Ferguson, L., Poss, J. A., Grattan, S. R., Grieve, C. M., Wang, D., Wilson, C. and Chao, C. T. (2002). Pistachio rootstocks influence scion growth and ion relations under salinity and boron stress. Journal of the American Society for Horticultural Science, 127(2), 194-199.

Field, C,, Merino, J., and Mooney, H. A. (1983). Compromises between water use efficiency and nitrogen-use efficiency in five species of California evergreens. Oecologia, 60, 384-389. doi:10.1007/BF00376856

Fitter, A. H., and Hay, R. K. M. (2002). Environmental physiology of plants. New York, NY, Academic Press

Flexas, J. and Medrano, H. (2002). Drought-inhibition of photosynthesis in C3 plants: stomatal and non-stomatal limitations revisited. Annals of Botany, 89(2), 183-189. doi:10.1093/aob/mcf027

Foyer, C. H., Lopez-Delgado, H., Dat, J. F. and Scott, I. M. (1997). Hydrogen peroxide-and glutathione-associated mechanisms of acclimatory stress tolerance and signalling. Physiologia Plantarum, 100(2), 241-254. doi:10.1111/j.13993054.1997.tb04780.x

Gill, S. S. and Tuteja, N. (2010). Reactive oxygen species and antioxidant machinery in abiotic stress tolerance in crop plants. Plant Physiology and Biochemistry, $\quad 48(12), \quad 909-930$. doi:10.1016/j.plaphy.2010.08.016

Havaux, M. (2014). Carotenoid oxidation products as stress signals in plants. The Plant Journal, 79(4), 597-606. doi: 10.1111/tpj.12386

Heath, R. L. and Packer, L. (1986). Photoperoxidation in isolated chloroplasts: I., Kinetics and stoichiometry of fatty acid peroxidation. Archives 
of Biochemistry and Biophysics, 125(1), 189-198. doi:10.1016/0003-9861(68)90654-1

Hishida, M., Ascencio-Valle, F., Fujiyama, H., OrduñoCruz, A., Endo, T., and Larrinaga-Mayoral, J. Á. (2014). Antioxidant enzyme responses to salinity stress of Jatropha curcas and J. cinerea at seedling stage. Russian Journal of Plant Physiology, 61(1), 53-62. doi:10.1134/S1021443714010063

Hoagland, D. R., Arnon, D. I. (1950). The water culture method for growing plants without soil. Circular. California Agricultural Experiment Station, 347, 132.

Hoekstra, F. A., Golovina, E. A. and Buitink, J. (2001). Mechanisms of plant desiccation tolerance. Trends in Plant Science, 6, 431-38. doi: 10.1016/S13601385(01)02052-0

Hokmabadi, H., Arzani, K., and Grierson, P. F. (2005). Growth, chemical composition, and carbon isotope discrimination of pistachio (Pistacia vera L.) rootstock seedlings in response to salinity. Crop and Pasture Science, 56(2), 135-144. doi:10.1134/S1021443714010063

Hopkins, W. G. (1999). Introduction to plant physiology (No. Ed. 2). John Wiley and Sons.

Jain, G. and Gould, K. S. (2015). Are betalain pigments the functional homologues of anthocyanins in plants? Environmental and Experimental Botany, 119, 48-53. doi:10.1016/j.envexpbot.2015.06.002

Jaleel, C. A., Gopi, R., Sankar, B., Manivannan, P., Kishorekumar, A., Sridharan, R. and Panneerselvam, R. (2007). Studies on germination, seedling vigour, lipid peroxidation and proline metabolism in Catharanthus roseus seedlings under salt stress. South African Journal of Botany, 73(2), 190-195. doi:10.1016/j.sajb.2006.11.001

Jennings, D. H. (1968). Halophytes, succulence and sodium in plants - a unified theory. New Phytologist, 67(4), 899-911. doi:10.1111/j.14698137.1968.tb06402.x

Karimi, S. and Rahemi, M. (2012). Growth and chemical composition of pistachio seedling rootstock in response to exogenous polyamines under salinity stress. Journal of Nuts, 3, 21-30.

Karimi, S., Hojati, S., Eshghi, S., Moghaddam, R. N. and Jandoust, S. (2012). Magnetic exposure improves tolerance of fig 'Sabz' explants to drought stress induced in vitro. Scientia Horticulturae, $\quad$ 137, 95-99. doi:10.1016/j.scienta.2012.01.018

Karimi, S., Mirfattahi, Z., Ferguson, L. and Tavallali, V. (2017). Using controlled salt stress and $\beta$ - aminobutyric acid signaling to decrease transplant failure. Scientia Horticulturae, 225, 156-162. doi: 10.1016/j.scienta.2017.06.070

Karimi, S., Rahemi, M., Eshghi, S., Maftoun, M. and Tavallali, V. (2009). Effects of long-term salinity on growth and performance of two pistachio (Pistacia vera L.) rootstocks. Australian Journal of Basic and Applied Sciences, 3(3), 1630-1639.

Karimi, S., Yadollahi, A. and Arzani, K. (2013). Responses of almond genotypes to osmotic stress induced in vitro. Journal of Nuts, 4(4), 1-7.

Keutgen, A. and Pawelzik, E. (2007). Modifications of taste-relevant compounds in strawberry fruit under $\mathrm{NaCl}$ salinity. Food Chemistry, 105(4), 1487-1494. doi:10.1016/j.foodchem.2007.05.033

Kim, I. and Park, S. (2010). Ultrastructural characteristics of three chenopod halophytes lacking salt excretion structures. Journal of Plant Biology, 53(4), 314-320. doi: 10.1007/s12374-0109119-6. doi:10.1007/s12374-010-9119-6

Larcher, W. and de Assis Prado, C. H. B. (2000). Ecofisiologia vegetal São Carlos: RiMa Artes e textos.

Lichtenthaler, H. K. (1987). Chlorophyll and carotenoids: Pigments of photosynthetic biomembranes. Methods in Enzymology, 148, 350382. doi:10.1016/0076-6879(87)48036-1

Maiale, S., Sánchez, D. H., Guirado, A., Vidal, A. and Ruiz, O. A. (2004). Spermine accumulation under salt stress. Journal of Plant Physiology, 161(1), 3542. doi:10.1078/0176-1617-01167

Mehta, P., Jajoo, A., Mathur, S. and Bharti, S. (2010). Chlorophyll a fluorescence study revealing effects of high salt stress on photosystem II in wheat leaves. Plant Physiology and Biochemistry, 48(1), 16-20. doi:10.1016/j.plaphy.2009.10.006

Miller, G. A. D., Suzuki, N., Ciftci- Yilmaz, S. U. L. T. A. N. and Mittler, R. O. (2010). Reactive oxygen species homeostasis and signaling during drought and salinity stresses. Plant, Cell and Environment, $33(4), \quad 453-467 . \quad$ doi:10.1111/j.13653040.2009.02041.x

Mittler, R. (2002). Oxidative stress, antioxidants and stress tolerance. Trends in Plant Science, 7(9), 405410. doi:10.1016/S1360-1385(02)02312-9

Miyamoto, S., Riley, T., Gobran, G. and Petticrew, J. (1986). Effects of saline water irrigation on soil salinity, pecan tree growth and nut production. Irrigation $\quad$ Science, $7(2), \quad 83-95$. doi:10.1007/BF00259425 
Morovati, I. (2013). Controlled pollinations to breeding of pistachio rootstock for salinity tolerance. College of Aburaihan, Tehran, Iran, Thesis, 95 p.

Munns, R. (2002). Comparative physiology of salt and water stress. Plant, Cell and Environment, 25(2), 239-250.

doi:10.1146/annurev.arplant.59.032607.092911

Munns, R. and Tester, M. (2008). Mechanisms of salinity tolerance. Annual Review of Plant Biology, 59 , 651-681. doi:10.1146/annurev.arplant.59.032607.092911

Nishida, Y., Yamashita, E. and Miki, W. (2007). Quenching activities of common hydrophilic and lipophilic antioxidants against singlet oxygen using chemiluminescence detection system. Carotenoid Science, 11(6): 16-20.

Omamt, E.N., Hammes, P.S. and Robbertse, P.J. (2006). Differences in salinity tolerance for growth and water-use efficiency in some amaranth (Amaranthus spp.) genotypes. New Zealand Journal of Crop and Horticultural Science, 34(1), 11-22. doi:10.1080/01140671.2006.9514382

Osone, Y., Ishida, A. and Tateno, M. (2008). Correlation between relative growth rate and specific leaf area requires associations of specific leaf area with nitrogen absorption rate of roots. New Phytologist, 179(2), 417-427. doi:10.1111/j.14698137.2008.02476.x

Ottow, E. A., Brinker, M., Teichmann, T., Fritz, E., Kaiser, W., Brosche, M., Kangasjarvi, J., Jiang, X. and Polle, A. (2005). Populus euphratica displays apoplastic sodium accumulation, osmotic adjustment by decreases in calcium and soluble carbohydrates, and develops leaf succulence under salt stress. Plant Physiology, 139: 1762-1772. doi:10.1104/pp.105.069971

Parida, A. K. and Das, A. B. (2005). Salt tolerance and salinity effects on plants: a review. Ecotoxicology and Environmental Safety, 3, 324-349. doi:10.1016/j.ecoenv.2004.06.010

Pérez-López, U., Robredo, A., Lacuesta, M., MenaPetite, A. and Munoz-Rueda, A. (2009). The impact of salt stress on the water status of barley plants is partially mitigated by elevated $\mathrm{CO}_{2}$. Environmental and Experimental Botany, 66(3): 463-470. doi:10.1016/j.envexpbot.2009.03.007

Piao, H. L., Lim, J. H., Kim, S. J., Cheong, G. W. and Hwang, I. (2001). Constitutive over-expression of AtGSK1 induces $\mathrm{NaCl}$ stress responses in the absence of $\mathrm{NaCl}$ stress and results in enhanced $\mathrm{NaCl}$ tolerance in Arabidopsis. The Plant Journal, 27(4), 305-314. doi:10.1046/j.1365313x.2001.01099.x
Rahemi, M., Karimi, S., Sedaghat, S. and Rostami, A. A. (2017). Physiological responses of olive cultivars to salinity stress. Advances in Horticultural Science, 31(1), 53-59. doi: 10.13128/ahs-20726

Rao, R. N., Udaykumar, M., Farquhar, G. D., Talwar, H. S. and Prasad, T. G. (1995). Variation in carbon isotope discrimination and its relationship to specific leaf area and ribulose-1,5-bisphosphate carboxylase content in groundnut genotypes. Functional Plant Biology, 22(4), 545551. doi:10.1071/PP9950545

Saadatmand, A. R., Banihashemi, Z., Maftoun, M. and Sepaskhah, A. R. (2007). Interactive effect of soil salinity and water stress on growth and chemical compositions of pistachio nut tree. Journal of Plant Nutrition, 30(12), 2037-2050. doi:10.1080/01904160701700483

Sefton, C. A., Montagu, K., Atwell, B. J. and Conroy, J. P. (2002). Anatomical variation in juvenile eucalypt leaves accounts for differences in specific leaf area and $\mathrm{CO}_{2}$ assimilation rates. Australian Journal of Botany, 50(3), 301-310. doi:10.1071/BT01059

Sevengor, S., Yasar, F., Kusvuran, S. and Ellialtioglu, S. (2011). The effect of salt stress on growth, chlorophyll content, lipid peroxidation and antioxidative enzymes of pumpkin seedling. African Journal of Agricultural Research, 6(21), 4920-4924. doi: 10.5897/AJAR11.668

Sherwin, H. W. and Farrant, J. M. (1998). Protection mechanisms against excess light in the resurrection plants Craterostigma wilmsii and Xerophyta viscosa. Plant Growth Regulation, 24(3), 203-210. doi: 10.1023/A:100580161089

Sperdouli, I. and Moustakas, M. (2012). Interaction of proline, sugars, and anthocyanins during photosynthetic acclimation of Arabidopsis thaliana to drought stress. Journal of Plant Physiology, 169(6), 577-585. doi:10.1016/j.jplph.2011.12.015

Szabados, L. and Savoure, A. (2010). Proline: a multifunctional amino acid. Trends in Plant Science, 15(2), 89-97. doi:10.1016/j.tplants.2009.11.009

Taiz, L. and Zeiger, E. 2002. Plant Physiology, Sunderland, Massachusetts. Sinauer Associates.

Tavallali, V., Rahemi, M. and Panahi, B. (2008). Calcium induces salinity tolerance in pistachio rootstocks, Fruits, $\quad 63(5), \quad$ 285-296. doi:10.1051/fruits:2008024

Verslues, P. E., Agarwal, M., Katiyar-Agarwal, S., Zhu, J. and Zhu, J. K. (2006). Methods and concepts in quantifying resistance to drought, salt and freezing, 
abiotic stresses that affect plant water status. The Plant Journal, 45(4), 523-539. doi:10.1111/j.1365313X.2005.02593.X

Wagner, G. J. (1979). Content and vacuole/extravacuole distribution of neutral sugars, free amino acids, and anthocyanin in protoplasts, Plant Physiology, 64(1), 88-93. doi:10.1104/pp.64.1.88

Wahome, P. K., Jesch, H. H. and Grittner, I. (2001). Mechanisms of salt stress tolerance in two rose rootstocks: Rosa chinensis 'Major'and $R$. rubiginosa. Scientia Horticulturae, 87(3), 207-216. doi:10.1016/S0304-4238(00)00168-0

Yaron, B., Zieslin, N. and Halevy, A. H. (1969). Response of Baccara roses to saline irrigation Journal of the American Society for Horticultural Science, 94, 481-484. 